\title{
Morphometrical Variation of Carob tree (Ceratoniasiliqua L) in Algeria.
}

\author{
Gadoum A ${ }^{1 *}$, Chahbar $\mathbf{M}^{2}$, Adda $A^{3}$, Sahnoune $M^{4}$ Aid $F^{1}$ \\ 1Laboratory of Biology and Physiology of Organisms, University of Sciences and Technology \\ HouariBoumediene Bab Ezzouar, Algeria \\ 2Laboratory of Agronomy and environment, Department of Biology, Faculty of Sciences and \\ Technology, University of Tissemsilt, Algeria \\ 3Laboratory of Plant Biotechnology and Genetic Improvement of Plants, University Ibn Khaldoun, \\ Tiaret, Algeria.
}

* Corresponding Author: GADOUM, A., HouariBoumediene University, Bab Ezzouar, Algeria.

Email: abdelkadergadoum@yahoo.fr

\begin{abstract}
Mediterranean ecosystems are subject to the influence of particular climatic conditions characterized by scarcity or irregular rainfall and long dry summer periods. These climatic restrictions generally disturb the vegetation. In order to overcome these problems. The use of pioneer tree species, adapted to climatic hazards, remains the most recommended solution. The carob tree (C.siliqua) is an agro-sylvo-pastoral species with enormous socioeconomic and ecological interests. This Mediterranean tree is favourably established in semi-arid and arid areas. For the success of reforestation projects, the management and preservation of this species requires prior assessment and characterization of their variability. This approach is based on multidisciplinary studies involving the analysis of the diversity of agro-morphological, adaptive traits. In this context, the present study aims to explore, using agro-morpho-metric markers of the carob tree in central and north-western Algeria. We use the pods and leaves to identify, label or characterize the different collections or germplasm of the carob tree in the world. This study was carried out on the variability of nine morpho-metric traits related to fruits (pods) and leaves through a comparative study at the level of provenances (Larabaa, BordjBounaama, Aflou, Remchi and Ain Sefra). Carob plants from three contrasting ecotypes of Ceratoniasiliqua (Remchi ecotype from the subhumid stage, Tissemsilt and BordjBounaama ecotype from the semi-arid stage and Ain Sefra and Aflou ecotype from the arid stage) were subjected to a thorough biometric study of the leaves and pods collected after a field survey in June-July 2013. The results showed the highest mean values for the majority of the traits studied, thus indicating the importance of the provenance factor. Based on the analyses of variance and their decomposition, and depending on the biometric traits studied, the carob resource management strategy can be chosen either for the pod factor (pod weight, pod length, number of seeds per pod and number of infested seeds per pod) or the leaf factor (petiole length and leaf area). In the case of our collections, the longest size was recorded in the Bordj Bounaama population $(16.66 \mathrm{~cm} \pm 2.36)$ and Remchi $(16.10 \mathrm{~cm} \pm 2.78)$ and the smallest in the Aflou population $(9.40 \mathrm{~cm} \pm 1,27)$. Indeed, a positive correlation between the measured parameters (length, width, thickness and weight of the pod) was observed. Differences between ecotypes were observed for all morphological traits studied.
\end{abstract}

Keywords: Carob tree, Pods, Leaves, Arid Stage, Biometric Traits

\section{Introduction}

The carob tree (Ceratoniasiliqua L., Fabaceae) is a forest spontaneous and cultivated species, and grows in the Mediterranean countries and climates.The carob fruit is a dark brown leathery pod that contains a soft rubbery pulp surrounding pleasant tasting seeds; it contains two main parts: the pod and the seeds(Tetiket al. 2011)The species progeny currently present in the Western Mediterranean would have an origin likea germaplasm introduced by the Arabs in the Iberian Peninsula during the medieval domination (Cairati, 2013).Assessing the variability of adaptive leaf characteristics is very useful for the pre-selection of elite trees, but it is still insufficient for a description of the genetic structure of Carob tree stands(Matthaus, and Ozcan. 2011).To this end, the exploitation of the polymorphism of 
environmentally neutral molecular markers is a complementary and very useful approach for the design of the management of phyto-genetic resources(Afif, Met al,2008)

Morphological and physiological traits have been traditionally used for the identification and management of carob tree cultivars (Gharnit and Ennabili 2015).Nowadays, they have been the main descriptive tools used to characterize a given collection or germplasm and to identify and differentiate wild types of cultivars (Crossa-Raynaud 1960, Navarro 1992, Touset al ., 1996).In order to alleviate this over-occupation and safeguard soil fertility and improve the living standard of the rural population, the use of multi-use pioneer tree species such as the carob tree, adapted to climatic hazards and able to settle on marginal land in reforestation and restoration of degraded lands remains a good strategy (Ait Chittet al., 2007; El Kahkahi et al, 2014). The choice of the fruit for this study emanates from the preference of several authors who have resorted to the use of different types of organs or devices, mainly pods, to identify, label or characterise the different collections or germplasms of the carob tree in the world. Thus, its fruits have been the subject of a large number of agromorphological and economic studies (Crossa-Raynaude, 1960; El-Hajajiet al, 2010). To differentiate local collections or compare them with those of other countries. Each pod trait is discriminating and could, in addition to its usefulness in the study of diversity, be of major interest in the empirical choice of cultivars or graft donors for the establishment of commercial orchards and according to each variable measured, one can characterise a particular accession or group of accessions. The total cultivated area of carob in the world is estimated at 87,485 ha, of which 74,174 ha $(84.81 \%)$ are distributed between Spain, Morocco, Italy and Portugal. Algeria's total area has declined sharply from 11,000 ha in 1961 to 1,000 ha in 2011 (Matthaus and Ozcan, 2011).National carob production is estimated at 33,841 qx and is mainly concentrated in the wilaya of Bejaia with a production of $18,417 \mathrm{qx}$, which represents $54.42 \%$ of national production, followed by the wilaya of Blida $(23.79 \%)$ and Tipaza $(16.55 \%)$. The area under carob cultivation in north-western Algeria (including the wilayas of Tlemcen and Mascara) is only 6 ha, or $0.65 \%$ of the national area, while carob production is only $0.39 \%$.

The carob tree (C.siliqua) belongs to the Leguminosae family of the Rosales order. It is a sclerophyllous, xerophilic, thermophilic, heliophilic and calcicole species, its origins are the arid and semi-arid zones of the Mediterranean and the Arab Peninsula. It is a tree that can play a particular interesting role, at both the socio-economic and ecological levels, especially in dry lands and in areas where desertification processes are becoming increasingly alarming, especially in the Mediterranean basin. The objective of this study was the morphological characterization of the pods and leaves of C.siliquafrom central and north-western Algeria.

\section{Materials and methods}

\section{Geographical description of experimental sites}

The climate of the study area is Mediterranean type for the Tellian region and continental type for the high steppe plains. The continental climate is known to be a harsh climate with significant temperature differences between winter and summer and between day and night. Summers are hot and winters cold with frequent frosts and little rainfall. These characteristics result from the location of these regions within the continents or from the fact that they are isolated by mountain massifs that prevent the maritime influence. This is the case of the Tellian Atlas, which acts as a screen against the steppe region, thus eliminating the influence of the Mediterranean.

As for the Mediterranean climate, it is temperate and is characterized by mild, wet winters and hot, dry summers. Temperatures are reasonable and rainfall is more or less abundant depending on the relief factor that characterizes the region, especially the mountain ranges. Thus, the rainfall recorded in the study area (northwest) is less than $600 \mathrm{~mm} /$ year. This low rainfall is due to the presence of the Moroccan Atlas, which acts as a screen eliminating the Atlantic influence on the north-western region of Algeria. 
The measurements were performed during the year 2013. All these Algerian donor regions belong to three bioclimatic, subhumid, semi-arid and arid stages with a rainfall of 600 to $900 \mathrm{~mm}$ for the first, more than 350 to $600 \mathrm{~mm}$ for the second and 100 to $300 \mathrm{~mm}$ for the latest.

Table 1. Geographic and climatic characteristics of sites in the five study areas of C.siliqua

\begin{tabular}{llllcccc}
\hline Study area & Wilayas & Latitude & Longitude & Altitude & Rainfall & $\mathrm{T}^{\circ}$ min & $\mathrm{T}^{\circ}$ Max \\
\hline Bordj Bounaama & Tissemsilt & $35.9049 \mathrm{~N}$ & $1.5248 \mathrm{~W}$ & $866 \mathrm{~m}$ & $400-600$ & $2-4^{\circ} \mathrm{C}$ & $33-38^{\circ} \mathrm{C}$ \\
\hline Larabaa & Tissemsilt & $35.9049 \mathrm{~N}$ & $1.5248 \mathrm{~W}$ & $866 \mathrm{~m}$ & $400-600$ & $2-4^{\circ} \mathrm{C}$ & $33-38^{\circ} \mathrm{C}$ \\
\hline Remchi & Tlemcen & $350300 \mathrm{~N}$ & $12600 \mathrm{~W}$ & $213 \mathrm{~m}$ & $600-800$ & $0-9$ & $29-33^{\circ} \mathrm{C}$ \\
\hline Aflou & Laghouat & $340650 \mathrm{~N}$ & $20550 \mathrm{~W}$ & $1310 \mathrm{~m}$ & $400-600$ & $-2-1{ }^{\circ} \mathrm{C}$ & $35-42^{\circ} \mathrm{C}$ \\
\hline Ain Sefra & Naama & $32.7439 \mathrm{~N}$ & $-0.8801 \mathrm{~W}$ & $2234 \mathrm{~m}$ & $100-300$ & $-10^{\circ} \mathrm{C}$ & $35-42^{\circ} \mathrm{C}$ \\
\hline
\end{tabular}

\section{Experimental materials}

The vegetal material consisted of pods and leaves of carob or was collected from different parts of Algeria. The pod lot of each of the five provenance regions is defined as accession. Thus, the accessions of Bordj Bounaama, Larabaa, Aflou, Remchi and Ain Sefra have been identified (Figure 1). In total, the fruits and leaves of five accessions were studied agro-morphologically. Five repetitions per line were carried out (one plant per repetition).

Phenotypic study based on the features of pods from different carob tree origins revealed an interaccess polymorphism. We distinguished 4 categories of accesses; the first category includes the Bordj Bounaama stands. The second group consists of two subgroups; one for Remchi samples and one for Larabaa samples. The third category includes samples of Ain Sefra while the last category includes samples of the Aflou ecotype.

\section{Data collection}

100 pods were randomly taken from each of the five accessions. Six discriminatory traits for pods were measured: length, width, and thickness, total fresh weight of pod, total number of seeds and number of aborted seeds. These measurements were taken in parallel with measurements made on 100 leaves of petiole length, leaflet number, and leaf area.

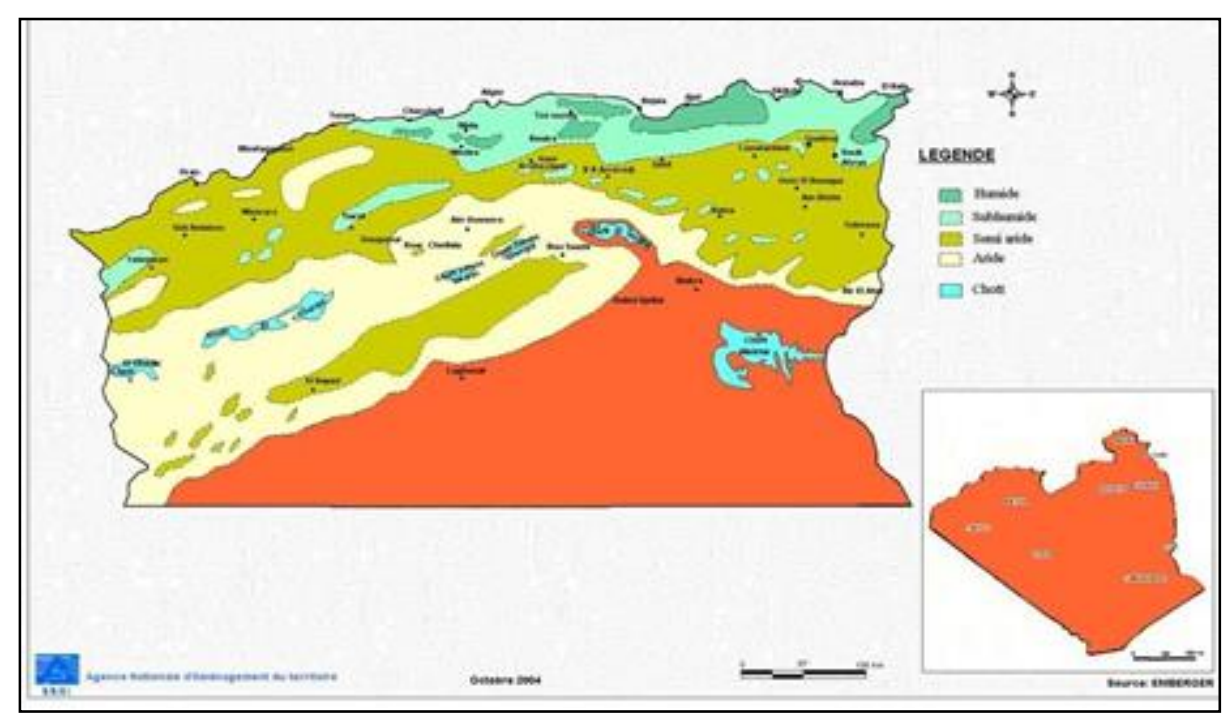

Figure 1. Bioclimatic map of Algeria showing the different localities where accessions have been collected. (ANAT, 2004)

\section{Pod biometry}


The length of the LNGS pod $(\mathrm{cm})$, the width of the LRGS pod $(\mathrm{mm})$ and the thickness of the EPG pod $(\mathrm{cm})$ were measured using a ruler and the weight of the PGS pod $(\mathrm{g})$ using a precision scale.

These measurements were carried out in parallel with counting the number of NGR/GS seeds and the number of aborted seeds per NGRAV/GS pod.
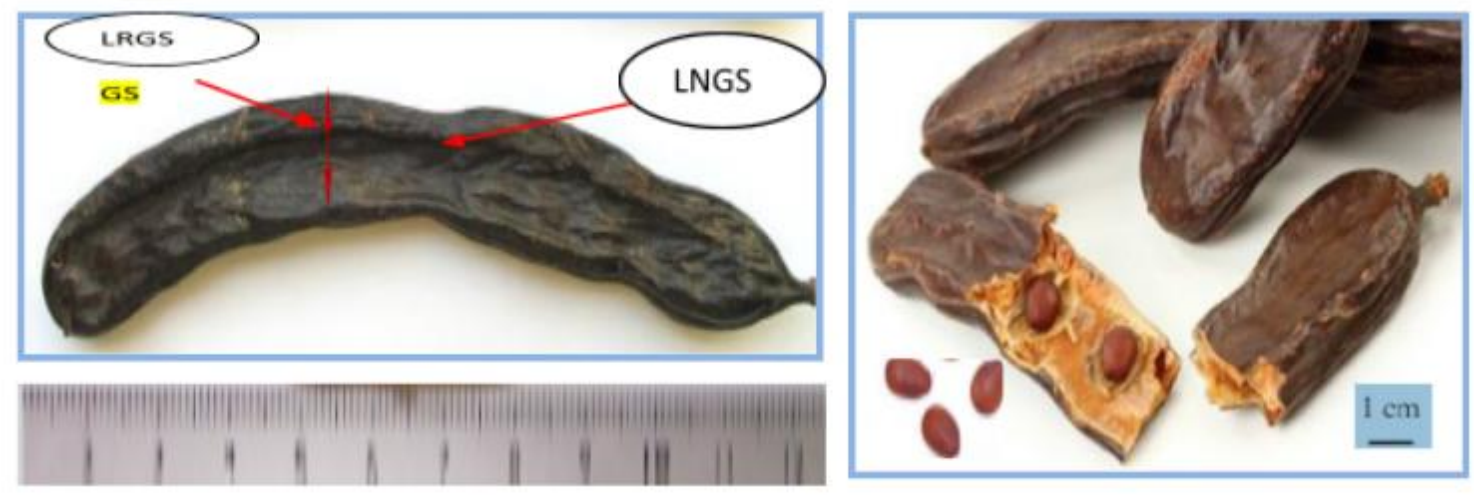

Figure 2. Morphometric measurements. A: length and width of the pod, B: number of seeds and aborted seeds.

\section{Leaf biometry}

The number of leaflets, the length of the petiole as well as the surface area of the leaves were determined. The length of the petiole was measured using wire ruler and graph paper. The surface of the sheets was established using the Mesurim software.

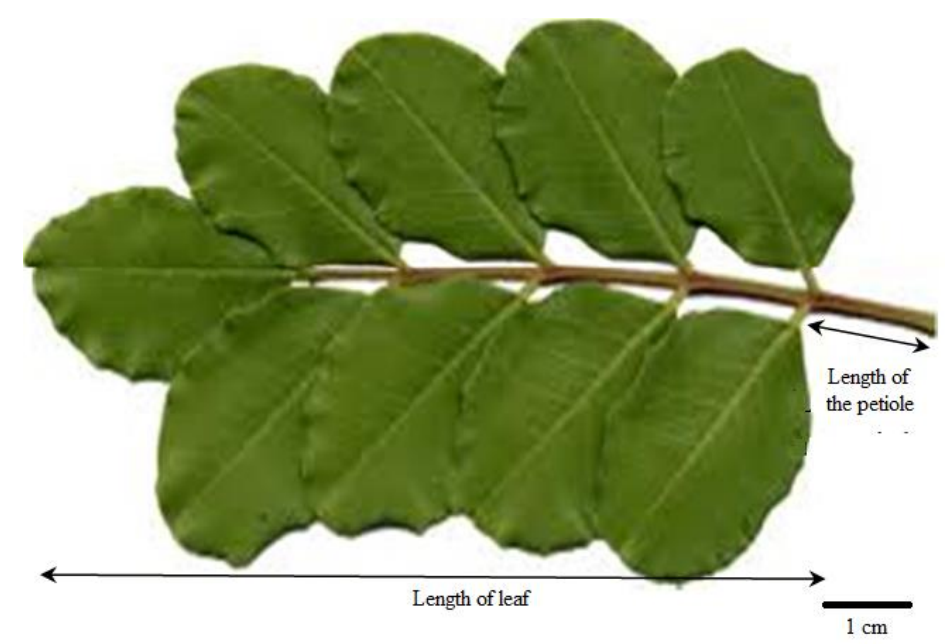

Figure 3. A descriptive diagram of a carob tree leaf.

Statistical analysis:

All statistical analyses are performed using SAS 9 windows software. The signification is chosen for a value of $p=0.05$. Pod and leaf biometric data are analyzed at different levels of tree structuring (intraand inter-provenances). A descriptive statistical analysis was first applied to our data using PROC MEANS procedure. The differences between provenances were detected by analysis of variance using a generalized linear model procedure (PROC GLM). The multiple comparisons between the different biometric parameters were performed using test of Waller-Duncan. The analysis of principal components (PCA) of provenances is performed to separate groups which are homogeneous. 


\section{Results and discussion}

Morphological variability was studied on mature pods using biometric measurements and qualitative assessments of the characteristics shown in Table 1. Biometric characters were studied in five provenances: Larabaa, BordjBounaama, Remchi, Aflou and Ain Sefra (Figure. 1, Table. 1).

\section{Pod characteristics}

The pods were characterized by six morphometric characters: length of pod $(\mathrm{cm})$, width of pod $(\mathrm{mm})$, weight of pod $(\mathrm{g})$, weight of pod $(\mathrm{g})$, number of seeds per pod and number of infested seeds per pod. The mean and standard deviation of the different traits observed during the experiment are presented in Table 2. Pod length: The size of the pods is defined by the average value of its length. In the case of our collections, the longest size was recorded in the Bordj Bounaama $(16.66 \pm 2.36 \mathrm{~cm})$ and Remchi $(16.10 \pm 2.78 \mathrm{~cm})$ ecotypes and the smallest in the Aflou ecotype $(9.40 \pm 1.27 \mathrm{~cm})$ (Figure. 3).

In addition, statistically significant differences were observed between ecotypes for all indicators of pod morphological variability of Ceratoniasiliqua ecotypes $(\mathrm{P} \leq 0.001)$ (Tab. 3 and Figure 3$)$.

Table 2. Agro-morphological characteristics (pod biometry) of the five accessions studied.

\begin{tabular}{|c|c|c|c|c|c|c|c|c|c|c|c|c|}
\hline & \multicolumn{2}{|c|}{$\begin{array}{l}\text { Pod weight } \\
\text { (g) }\end{array}$} & \multicolumn{2}{|c|}{ Length(cm) } & \multicolumn{2}{|c|}{ Width (cm) } & \multicolumn{2}{|c|}{ Thickness (mm) } & \multicolumn{2}{|c|}{ Number of seeds } & \multicolumn{2}{|c|}{$\begin{array}{l}\text { Number of } \\
\text { aborted } \\
\text { seeds }\end{array}$} \\
\hline & Moy & SD & Moy & SD & Moy & SD & Moy & SD & Moy & SD & Moy & SD \\
\hline BBN & 14,13 & 3,48 & 16,66 & 2,36 & 1,89 & 0,20 & 1,04 & 0,24 & 6,65 & 1,88 & 1,19 & 0,25 \\
\hline Larabaa & 7,26 & 1,21 & 13,72 & 1,34 & 1,68 & 0,15 & 0,46 & 0,18 & 11,35 & 2,20 & 0,87 & 0,39 \\
\hline Aflou & 2,83 & 0,45 & 9,40 & 1,27 & 1,30 & 0,19 & 0,24 & 0,15 & 9,52 & 1,93 & 0,35 & 0,16 \\
\hline Remchi & 11,93 & 2,92 & 16,10 & 2,78 & 1,68 & 0,13 & 0,67 & 0,11 & 10,11 & 2,59 & 0,38 & 0,12 \\
\hline $\begin{array}{l}\text { Ain } \\
\text { Sefra }\end{array}$ & 5,66 & 0,89 & 15,63 & 2,52 & 1,92 & 0,27 & 0,49 & 0,14 & 12,27 & 2,00 & 0,79 & 0,18 \\
\hline
\end{tabular}

Moy: average

Pod width: The width of the pods is between $1.30 \mathrm{~cm}$ and $1.92 \mathrm{~cm}$, corresponding to an average of $1.68 \pm 0.26 \mathrm{~cm}$. The pods of Ain Sefra are wide pods with a value of $1.92 \pm 0.27 \mathrm{~cm}$, while the smallest width was recorded in theAflou ecotype $(1.30 \pm 0.19 \mathrm{~cm})$.

The results of the ecotype effect on the "pod width" characteristic were shown in Table 02 and Figure 04. For all ecotypes studied, there was a significant difference in pod width $(\mathrm{P}<0.001)$.

Pod thickness: Significant differences in pod thickness were recorded between the accessions studied ( $p<0.0001$ four different classes were obtained (Figure. 04). This trait is therefore strongly influenced by the ecotype effect $(\mathrm{P}<0.001)$ and is more pronounced in the BordjBounaama ecotype, whereas the Aflou ecotype is characterized by the lowest value of pod thickness $(0.24 \pm 0.15 \mathrm{~mm})$ (Figure.4).

Significant differences exist between the five provenances of C.siliqua for the thickness of the pods (Table 2). The thickness of the pods showed significant and stable inter-provenance differences. 


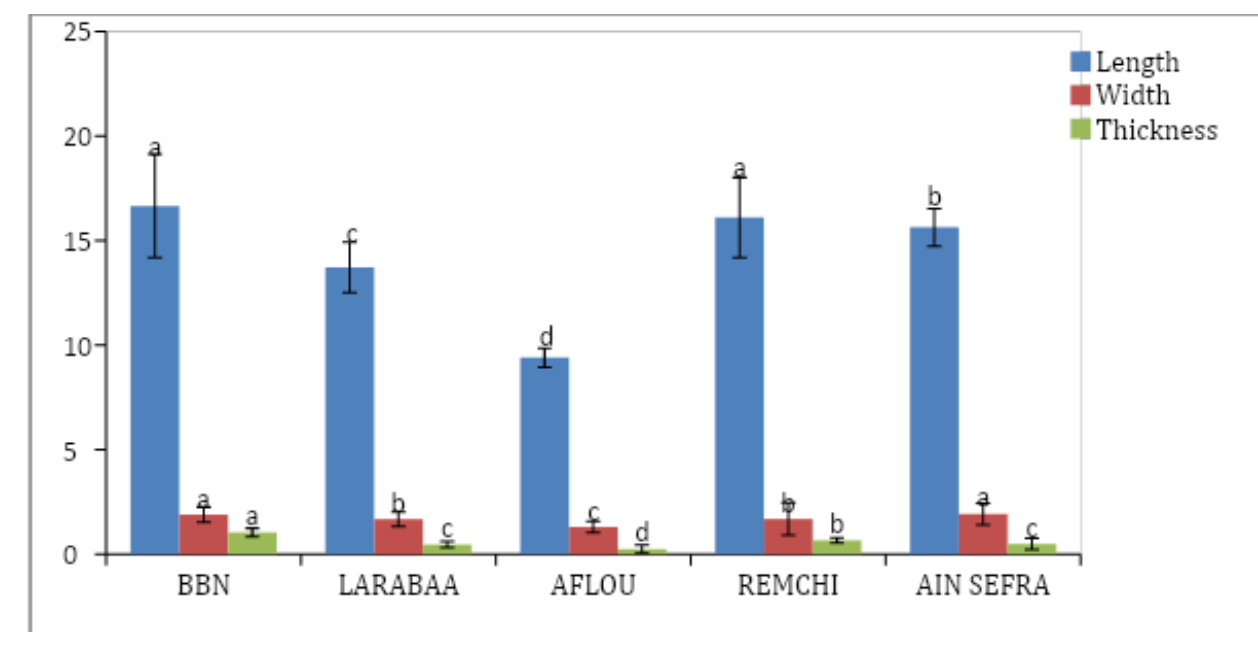

Figure 4. Effect of provenance on the length, width and thickness of pods of five C. siliqua ecotypes. mean $\pm \operatorname{SE}(n=100)$.

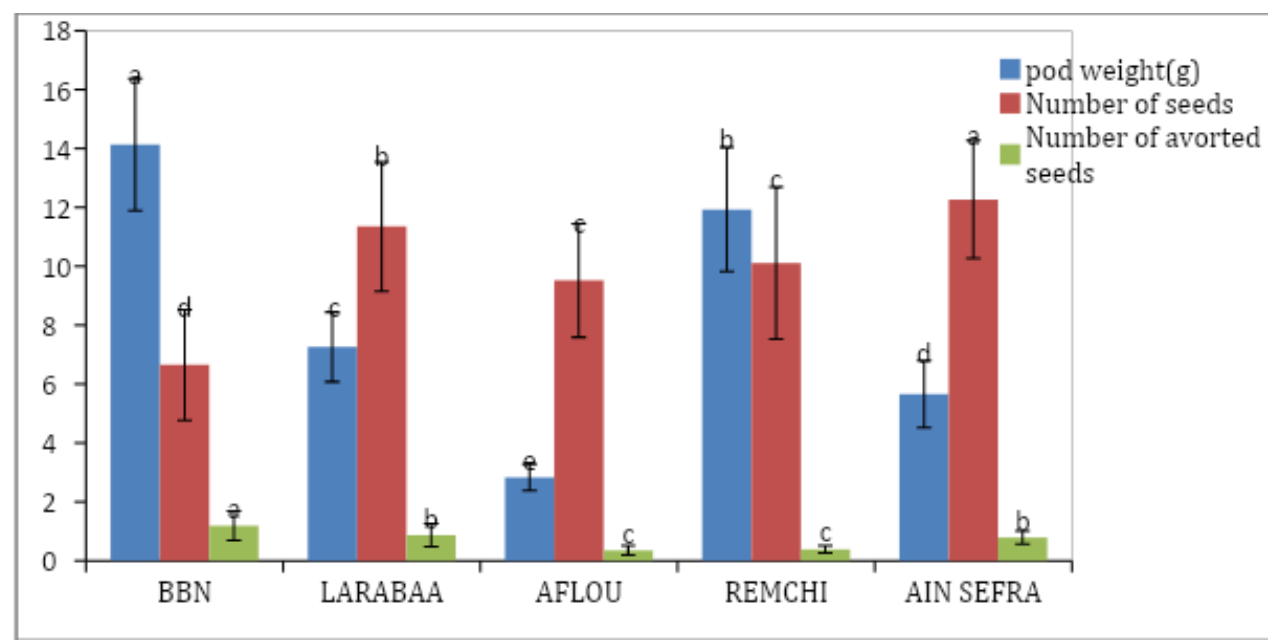

Figure 5. Effect of provenance on pod weight, number of seeds and number of aborted seeds of the five C. siliqua ecotypes. mean $\pm \operatorname{SE}(n=100)$.

Pod weight: The Aflou ecotype showed the lowest pod weight among the five ecotypes studied with $2.83 \pm 0.45 \mathrm{~g}$ (Figure. 5 and Table. 2).

The variables length, width and thickness of the pod are directly related to the weight of the pod (Figure 5). Indeed, a positive correlation between the measured parameters (length, width, thickness and pod weight) was observed. Heavy weight pods are those with long, wide and thick pods. A significant difference $(\mathrm{P}<0.001)$ for the pod weight trait was found. An ecotype effect was noted at significance level $\mathrm{P}<0.001$ (Table 2).

Number of total and aborted seeds: The average number of seeds per pod is highly variable. The Bordj Bounaama ecotype has the lowest number of seeds per pod and the Ain Sefra ecotype the highest number of seeds with $12.27 \pm 2.00$ seeds per pod.

In addition, the average number of aborted seeds per pod varies from 0.35 to 1.19 and the highest number of aborted seeds was recorded in the Bordj Bounaama ecotype (1.19 \pm 0.25 aborted seeds per pod) and the lowest in theAflou ecotype $(0.35 \pm 0.16)$ (Table. The results of the analysis of variance confirmed the existence of differences in the overall morpho-metric characteristics of the ecotypes 
(Table. 3). Thus, the calculated F (Fisher-Snedecor) statistic also indicated very good significance (P $<.0001)$ for all morpho-metric traits studied.

Table 3. Analysis of variance (dF: degree of freedom, F: value of F and P: probability.

\begin{tabular}{cccc}
\hline & DF & F & P \\
\hline Podweight & 4 & $460.47^{* * *}$ & $<.0001$ \\
\hline Podlength & 4 & $191.89^{* * *}$ & $<.0001$ \\
\hline Podwidth & 4 & $164.59^{* * *}$ & $<.0001$ \\
\hline Podthickness & 4 & $24.74^{* * *}$ & $<.0001$ \\
\hline Number of seeds & 4 & $91.80^{* * *}$ & $<.0001$ \\
\hline Number of abortedseeds & 4 & $15.90^{* * *}$ & $<.0001$ \\
\hline Petiolelength & 4 & $26.24 * * *$ & $<.0001$ \\
\hline Number of leaflets & 4 & $105.83^{* * *}$ & $<.0001$ \\
\hline Leaf area & 4 & $33.48^{* * *}$ & $<.0001$ \\
\hline
\end{tabular}

Leaf characteristics: Table 4 presents the characteristics of the leaves taken from the five ecotypes studied.

Leaf area: The statistical study of the results (Table. 4) shows that the leaf area is strongly influenced by the environmental factors of our accessions $(\mathrm{P}<0.05)$. The origin of accessions has a highly significant effect on the expression of this parameter $(\mathrm{P}<0.05)$; the ecotypes tested react differently to climatic conditions. The leaf area of trees of the Larabaa ecotype is the largest (Figure. 6) and the smallest was observed in trees of the Aflou ecotype. (Table. 4).

Thus, the highest leaf area values were noted in theLarabaa ecotype $\left(57.66 \pm 16.97 \mathrm{~cm}^{2}\right)$ and the Ain Sefra ecotype. $\left(52.15 \pm 10.44 \mathrm{~cm}^{2}\right)$. Nevertheless, we found that leaf area values ranged from $34.85 \pm$ $18.46 \mathrm{~cm}^{2}, 34.06 \pm 9.07 \mathrm{~cm}^{2}$ to $37.90 \pm 13.54 \mathrm{~cm}^{2}$ for the Bordj Bounaama, Aflou and Remchi ecotypes, respectively.

Table 4. Agro-morphological characteristics (leaf biometry) of the five accessions studied (100 observations).

\begin{tabular}{ccccccc}
\hline & \multicolumn{2}{c}{ Number of leaflets } & \multicolumn{2}{c}{ Petiole length } & \multicolumn{2}{c}{ Leaf area $(\mathrm{cm} 2)$} \\
\hline & Average & SD & Average & SD & Average & SD \\
\hline BBN & 5.46 & 2.05 & 10.07 & 1.74 & 34.85 & 18.46 \\
\hline LARABAA & 10.55 & 2.57 & 11.86 & 0.67 & 57.66 & 16.97 \\
\hline AFLOU & 8.02 & 0.95 & 9.65 & 1.94 & 34.06 & 9.07 \\
\hline REMCHI & 8.05 & 0.98 & 10.92 & 1.83 & 37.90 & 13.54 \\
\hline AIN SEFRA & 9.23 & 2.01 & 12.60 & 2.51 & 52.15 & 10.44 \\
\hline
\end{tabular}

Petiole length: Environmental conditions also have a significant influence on petiole length. The extreme values of petiole length are $20.01 \mathrm{~cm}$ and $4.53 \mathrm{~cm}$, with an average of $12.60 \pm 2.51 \mathrm{~cm}$ in the Ain Sefra ecotype (Table 4). During our study, the Aflou ecotype showed the lowest petiole length $(9.65 \pm 1.94 \mathrm{~cm})$ compared to the Ain Sefra ecotype which showed the highest value of petiole length $(16.60 \pm 2.51 \mathrm{~cm})$. Based on the analysis of variance, the ecotype effect was found to be highly significant for this morphological trait $(\mathrm{P}<0.001)$ (Table 3).

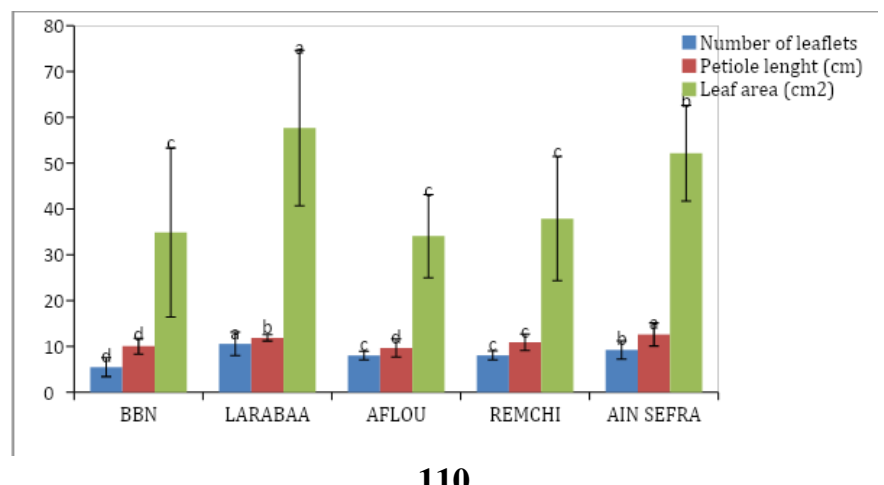

110 
Figure 6. Effect of provenance on leaf area, petiole length and number of leaflets of five C.siliqua ecotypes. Mean \pm SE $(n=100)$.

Number of leaflets: Analysis of variance shows highly significant differences for all ecotypes studied $(\mathrm{F}=105.83 * * *, \mathrm{P}<0.001)$. The highest number of leaflets per leaf was recorded in the Larabaaecotype $(10.55 \pm 2.57)$ and the lowest in theBordjBounaama ecotype $(5.46 \pm 2.05)$.

Significant differences $(\mathrm{P}<0.001)$ in leaflet number, petiole length and leaf area were observed in Ceratoniasiliqualeaves from different accessions (Table. 4).

\section{Canonical Analysis}

Principal Component Analysis (PCA) of the biometric parameters of the pod showed four distinct groups (Figure. 7 and 8); the first group includes stands located in the BordjBounaama region.

The second group consists of two subgroups; one made up of all the samples from the Remchi region and the other made up of the Larabaa samples. The third group includes stands located in the Ain Sefra region and the last group includes samples of the Aflou ecotype (Figure. 7) for all ecotypes, the square distance values are less than 50, indicating overlaps between them.

Figure 7 shows the projection of the midpoints of the colonies on the foreground of a PCA. The statistical $\mathrm{F}$ values and square distances between the Larabaa and BordjBounaama ecotypes (two-bytwo comparison) represent a very highly significant difference with all other ecotypes. These results indicate that Larabaa and BorjBounaama are considered to be the two most morphologically distant ecotypes. For the rest of the ecotypes Ain Sefra, Remchi and Aflou, the values of the square distance (D2) are less than 50, indicating overlaps between them. Samples of the three ecotypes Remchi, Aflou and Ain Sefra form a separate group.

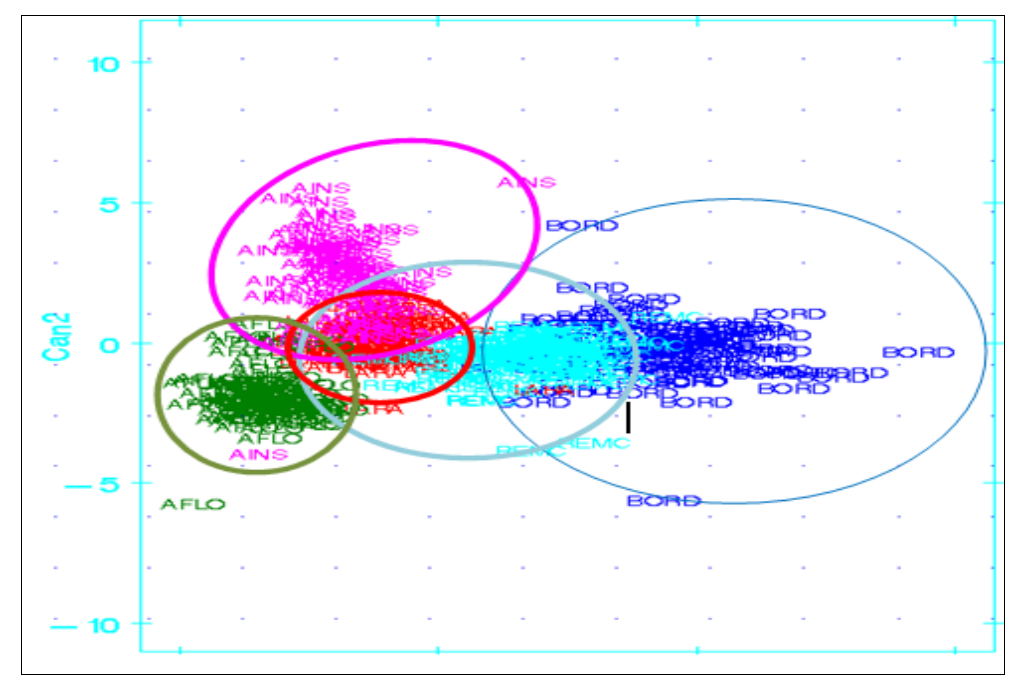

Figure 7. Projection of mean points of the regions studied on the first factorial plane of a principal component analysis.AINS:Ain sefra, BORD: Bordj bounaama, AFLO: Aflou,REMC: Remchi, LARA: Larabaa. 


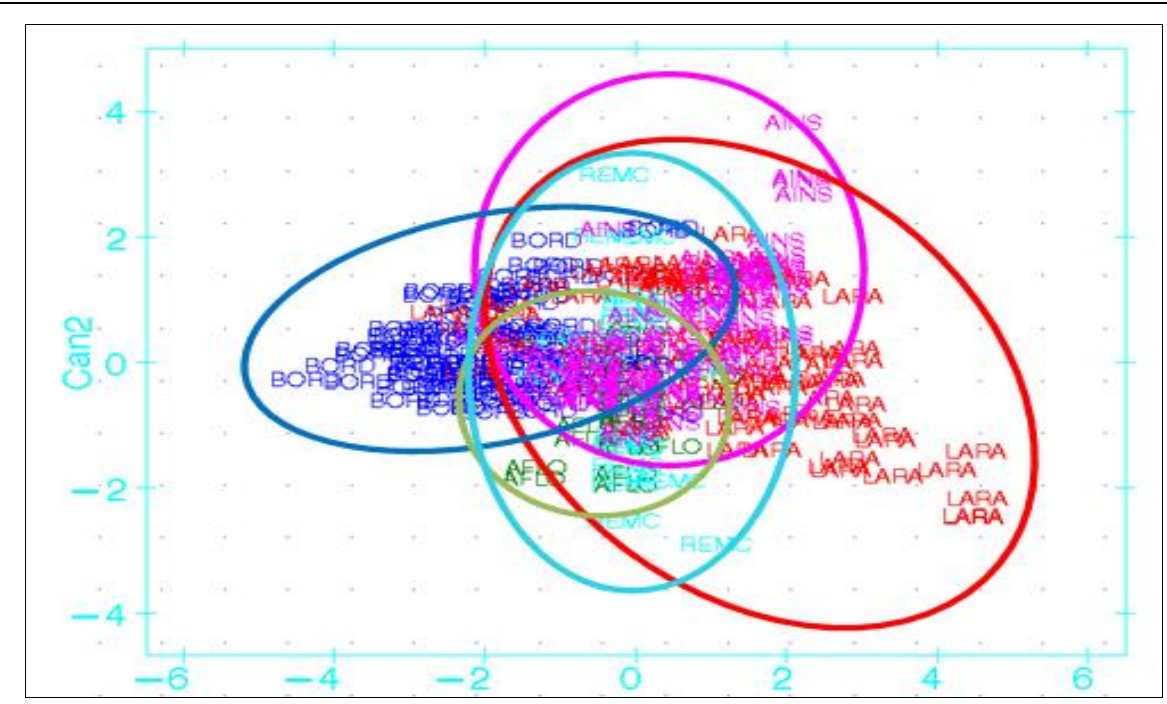

Figure 8. Projection of mean points of the regions studied on the second factorial plane of a principal component analysis. AINS: Ain sefra,BORD: Bordj bounaama, AFLO: Aflou,REMC: Remchi, LARA: Larabaa.

\section{Discussion}

Each pod criterion can be considered as a means of distinguishing accessions; each of the six traits studied could, agro-morphologically, discriminate our carob tree accessions. Fruits have been the subject of a large number of agro-morphological and economic studies (Navarro, 1992; Touset al., 1996; Batlle et Tous, 1997; Gharnitet al., 2001) as have its inflorescences and flowers (Linskens and Schlten, 1980; Retanaet al.,1994; Gharnitet al.,2004; Salinas, et al.2015) to differentiate local collections or compare them with those of other countries. Each pod trait is discriminating and could, in addition to its usefulness in the study of diversity, be of major interest in empirical selection for cultivar selection.

Pod size, defined by the average value of its length, has led to the classification of our accessions into three categories: slightly long size $(15<\mathrm{L} \leq 20 \mathrm{~cm})$, medium size with $(14 \leq \mathrm{L} \leq 15)$ and slightly short size with $(10 \leq \mathrm{L}<14)$, in accordance with the work on size categorization carried out by Tutinet al. (1993), Touset al. (1996) and Batlle et Tous (1997). In the case of our study, we can classify the pods of the Ain Sefra, Remchi and Bordj Bounaama accessions as slightly long pods, while those of the Larabaa and Aflou accessions are characterized by short pods.

The width of the pods of the carob tree is an important agronomic indication. It is independent of pod size and can provide information not only on its compressed or expanded state, but also on the volume of seeds and pulp. It varies from 1.5 to $2.5 \mathrm{~cm}$ according to Tutin et al. (1993) and from 1.5 to $3.5 \mathrm{~cm}$ according to Batlle and Tous (1997). The thickness of the pods also varies from one accession to another and is a criterion for distinguishing between compressed or bulky pods. It can reach up to 1 $\mathrm{cm}$, especially in fleshy pods (Batlle and Tous, 1997). The highest pod thickness was recorded in the Bordj Bounaama ecotype, and the lowest values were recorded in the Aflou ecotype (0.24 \pm $0.15 \mathrm{~cm}$ ).Pod weight is a distinctive criterion in agro-morphological terms, but it is always related to and influenced by measurements of size (length, width and thickness). In fact, we have observed that, in general, accessions with a high pod weight are those with long, wide and thick pods.

The levels of variation in pod weight are very comparable between the five ecotypes studied; the mean, minimum and maximum values show a difference between our ecotypes depending on climatic conditions. In fact, carob pod weight values remain virtually unchanged under the same environmental conditions (Melgarejo and Salazar, 2003). These results are in agreement with those of Melgarejo and Salazar, (2003); Ait Chitt et al. (2007) and El Kahkahi et al. (2014), confirming that carob tree 
production in fruit quality (pods) is a function of variety, environmental conditions, pollination efficiency and technical management.

The average number of seeds per pod of the different accessions is very variable. The pods with the highest number of seeds are those from Ain Sefra (12.27 \pm 2.00 seeds) and Larabaa (11.35 \pm 2.20 seeds), those with an average number of seeds are those from Aflou and Remchi with $9.52 \pm 1.93$ seeds and $10.11 \pm 2.59$ seeds respectively and those with the lowest number of seeds are those from Bordj Bounaama individuals with $6.65 \pm 1.88$ seeds. The abundance of seeds in the pods of a carob production would be a distinguishing feature between wild types and cultivars. Wild types are known for their high production of seeds, which are generally small and non-fleshy (without a thick husk) (Marakis et al., 1988; Ouchkif, 1988; Di Lorenzo, 1991).

In addition, the fruits of the different accessions contain a varying number of aborted seeds. We noted that the average number of aborted seeds per pod ranged from 0.6 to 2.51 and the highest number of aborted seeds was recorded in the Bordj Bounaama pods with 2.51 aborted seeds per pod, and the lowest number of aborted seeds was observed in the Aflou and Remchi pods with 0.38 and 0.39 aborted seeds respectively.

Leaves are partially bipinnate or double compound, reminiscent of the leaves of Gleditsiatriacanthos (Tutin et al. 1990-93) and the number of leaflets per leaf may be as high as 16 leaflets (Fournier, 1977; Feki, 2011). Leaf area is affected by the impact of the environment. According to the analysis of variance, significant differences exist between the different ecotypes. The recorded values of leaf area in our ecotypes range from $57.66 \mathrm{~cm} 2$ in Larabaa to $34.06 \mathrm{~cm} 2$ in Aflou. The ecotypes studied generally show moderate development of petiole length and leaflet number. This could be related to the stages of fruit production, especially in the older stages. Overall, the decrease in rainfall causes a loss of leaf area in all ecotypes studied. It is a frequent response of plants under water stress (Granier and Tardieu, 2000). Leaf area is a morphological character of adaptation to abiotic constraints (Attia, 2007). This decrease is a sign of reduced water loss and therefore better drought tolerance. These changes result from a decrease in the rate of division of the cells that make up plant tissue (Bousba et al., 2009).

\section{Conclusion}

Based on the results of our study, significant differences in the studied properties were detected within the same genotype and between provenances. The analysis of the diversity of the studied carob genotypes by an agro-morphometric approach allowed the selection of genotypes adapted to the environmental conditions. In addition, the length and width and weight of the pod and the leaf area could be very useful criteria for selecting plants with high agro-industrial potential.

Furthermore, the provenances of Bordj Bounaama and Remchi showed high mean values for the majority of the studied traits. The pre-selection approach for possible seed orchards can be initiated by exploiting the data collected on the tree and on the provenance. Thus, depending on the distribution of genotypes that exceed the average of all provenances for the studied traits, one can opt for the resource management strategy of carob tree or for the provenance factor.

The assessment of the variability of adaptive traits is very useful for the pre-selection of elite trees, but it remains insufficient for a description of the genetic structure of carob stands. The indeterminate diversity of North western Algerian carob species is partly genetic, and the source (accession) has an influence in this respect. In general, the morphological relationship between carob accessions differs profoundly from the molecular relationship. 


\section{References}

Afif M. Messaoud C. Boulila A 2008. Genetic structure of Tunisian natural carob tree (Ceratoniasiliqua L.) populations inferred from RAPD markers. Ann. For. Sci. 65, 710.).

Ait Chitt M.Belmir H. Lazrak A 2007. Production de plants sélectionnés et greffés de caroubier. Transfert de technologie en agriculture. Maroc. $\mathrm{N}^{\circ} 153: 1-4$.

ANAT (Agence nationale de l'aménagement du territoire) 2004. Carte bioclimatique de l'Algérie.

Attia F 2007.effet du stress hydrique sur le comportement ecophysiologique et la maturitephenolique de la vigne vitisvinifera 1.:etude de cinq cepages autochtones de midi-pyrenees. PhD thèse. De L'institut National Polytechnique De Toulouse. 194 p.

Batlle I. Tous J 1997.Carob tree. Ceratoniasiliqua L. Promoting the conservation and use of underutilized and neglected crops. 17. Institute of Plant Genetic and Crops Plant Research. Gatersleben/International Plant Resources Institute. Rome. Italy.

Bousba R. Ykhlef, N. Djekoun A 2009. Water use efficiency and flag leaf photosynthetic in response to water deficit of durum wheat (Triticum durum Desf.). World J. Agr. Sci. 5: 609-616.

Cairati E. 2013. Historia cultural delalgarrobo, desde la cuencadelMediterráneohasta la Costa Norte de Perú. OtherModernities. 10:186-204.

Crossa-Raynaud P. 1960. Caroubiers. Annales Inst. Nat. Recherche Agric. Tunisie. 33:79-83.

Di Lorenzo R 1991.CarruboFrutticolturaspeciale. Ed. REDA, Rome.

El-Hajaji H. Lachkar N. Alaoui K. Cherrah Y. Farah A. Ennabili A. El-Bali B. Lachkar M 2010. Antioxidant Properties and Total Phenolic Content of Three Varieties of Carob Tree Leaves from Morocco. Rec. Nat. Prod. 4:193-204.

El Kahkahi R. Zouhair R. AitChitt M. Errakhi R 2014.Morocco carob (Ceratoniasiliqua L.) populations: Morphological variability of Pods and Kernel International of pure and applied biosciences. 2 (4): 38-47.

Feki AE 2011. Characterization of bioactive compounds and ameliorative effects of Ceratoniasiliqua leaf extract against $\mathrm{CCl}$ 4induced hepatic oxidative damage and renal failure in rats. Food Chem. Toxicol. 49:3183-3191.

Fournier. P 1977. Les quatre flores de la France (générale, alpine, méditerranéenne, littorale). Le Chevalier, Paris (France).

GadoumA. Adda A. Sahnoune M. Aid F 2019.Physiological and biochemical responses of three ecotypes of carob (CeratoniasiliquaL.) against drought stress in Algeria. Applied ecology and environmental research 17(2):1929-1945.

Gharnit N. EtMtili N. Ennabili A. T. Ennabili A 2001. Social characterization and exploitation of carob tree (CeratoniasiliquaL.) from Mokrisset and Bab Taza (NW of Morocco). Sci. Lett. $3 \mathrm{n}^{\circ} 2$.

Gharnit N. El Mtili N. Ennabili A. Sayah F 2004. Floral characterization of carob tree (CeratoniasiliquaL) from the province of Chefchaouen (NW of Morocco). Moroccan J. Biol. 1:4151.

Granier C. Inzé D. Tardieu F. 2000.Spatial distribution cell division rate can be deduced from that of $\mathrm{P} 34 \mathrm{cdc} 2$ kinase activity in maize leaves grown in contrasting conditions of temperature and water status. Plant Physiology 124: 1393-1402.

Konate I. 2007.Diversité Phénotypique et Moléculaire du Caroubier (Ceratoniasiliqua L.) et des Bactéries Endophytes qui lui sont Associées. PhD thèse. Univ. Mohammed v-Agdal. 196 p.

Linskens H. Scholten W 1980. The flower of carob. Potug. Acta. Bilo. (A) XVI (1-4):95-102.

Marakis, S. Kalaitzakis J. Mitrakos K 1988.Criteria for recognizing carob tree varieties. In: Fito, P., Mulet, A. (Eds.), Proceedings of the II International Carob Symposium Valencia, Spain, pp. 558566.

Matthaus B. Ozcan MM 2011. Lipid evaluation of cultivated and wild carob (Ceratoniasiliqua L.) seed oil growing in Turkey. Sci. Hort. 130:181-184.

Melgarejo P. Salazar DM 2003.Tratado de fruticultura para zonas áridas y semiáridas. Vol. II. Mundi-Prensa. España, pp. 19-162. 
Gharnit. N. Ennabili. A 2015. Categories of CarobTree (Ceratoniasiliqua L.) from Morocco, International Journal of Fruit Science

Navarro V. 1992.Estudio y mejoradelalgarrobo. In II Jornadas Sobre experimentacion en fruticultura. Moncada, Valencia (Espana).

Ouchkif M 1988. Effet de l'incorporation de proportions élevés de pulpe de caroube sur la digestibilité et l'utilisation de le ration par les Agneaux à l'engraissement. Mémoire de 3ème cycle. IAV Hassan II, Rabat (Maroc).

Retana J. Ramoneda J. Garcia delPino F. Bosch J 1994. Flowering phenology of carob, CeratoniasiliquaL. (Caesalpinaceae). J. Hort. Sci. 69(1):97-103

Salinas MV. Carbas B. Brites C 2015. Influence of Different Carob Fruit Flours (Ceratoniasiliqua L.) on Wheat Dough Performance and Bread Quality. Food Bioprocess Technol8, 1561-1570 ().

Tetik N. Turhan I. Oziyci HR. Gubbuk H. KarhanM. Ercisli S 2011. Physical and chemical characterization of Ceratoniasiliqua L. germplasm in Turkey. ScientiaHorticulturae-Amsterdam, $129,583-589$.

Tous J. Romero A. Plana J. Battle I 1996. Current situation of carob plant material.In proceeding of the III International carob symposium. Cabanas-Tavira, Portugal.

Tous J and Batlle I 1990. El Algarrobo. Ed. Mundi-Prensa. Madrid (Espana).

Tutin TG. Burges NA. Chater AO. Edmondson Heywood VH. Moore DM. Valetine DH. Waters S.M. Webb DA 1993. Flora Europaea. Cambridge University Press. UK. 